\title{
Excretion of Hydroxyproline in Urine by Premature and Normal Full-Term Infants and Those with Intrauterine Growth Retardation During the First Three Days of Life
}

\author{
M.K. YounoszaI ${ }^{[28]}$ and J.C. Haworth \\ Winnipeg General Hospital and the Department of Pediatrics, University of Manitoba, Canada
}

Extract

The mean daily urinary excretion of hydroxyproline on the first day of life was $4.4 \mathrm{mg} / 24 \mathrm{~h}$ for 50 fullterm normal infants, $3.5 \mathrm{mg} / 24 \mathrm{~h}$ for 17 full-term infants with intrauterine growth retardation (IUGR) and $5.5 \mathrm{mg} / 24 \mathrm{~h}$ for 17 premature infants. The differences were not statistically significant. On the third day of life, all infants excreted significantly higher amounts of hydroxyproline in their urine. The mean amount excreted by full-term normal infants and by premature infants was about the same, $9.9 \mathrm{mg} / 24 \mathrm{~h}$ and $9.6 \mathrm{mg} / 24 \mathrm{~h}$, respectively, significantly more than that excreted by IUGR infants, $7.0 \mathrm{mg} / 24 \mathrm{~h}$.

Fifteen full-term normal infants fed a soya formula for the first week of life excreted almost the same amount of endogenous creatinine in the urine on the first, third and seventh day of life. The means in $\mathrm{mg} / 24 \mathrm{~h}$ were $24.2,24.3$ and 22.5 , respectively. The hydroxyproline to creatinine ratio doubled on the third day of life.

\section{Speculation}

The increase in the amount of hydroxyproline excreted in urine during the first few days of life may prove to be of value in assessing normal and abnormal rates of perinatal growth. Measurements of the amount of hydroxyproline in urine may provide a good index of perinatal growth, and the rapid increase in excretion soon after birth seems to indicate the initiation of a phase of rapid growth.

\section{Introduction}

The rate of urinary excretion of endogenous hydroxyproline, both free and in peptide form, is related to the metabolic state and total mass of body collagen [2, 13, 21]. A major part of body collagen is contained in bone, and the rate of turnover of collagen in bone exceeds that in other tissues [19]. It has been assumed, therefore, that urinary excretion of hydroxyproline mainly reflects the rate of metabolism of collagen in bone [5, $7,10,11,18]$. The normal range of urinary hydroxy-

2 Pediat. Res., Vol. 2, No. 1 (1968) proline during infancy, childhood and adolescence has been defined and it has been shown that during periods of rapid linear growth, the amount of total hydroxyproline excreted increases $[8,9,26]$. There is little information, however, about hydroxyproline excretion during the first few days of life. The purpose of this study was to establish for the normal full-term infants the hydroxyproline excretion in urine during the first three days of life and to compare these values with those found in patients with intrauterine growth retardation (IUGR) and in premature infants. 
Subjects and Methods

The subjects consisted of the following: (1) 50 normal full-term infants with birth weights ranging from 2720 to $4140 \mathrm{~g}$; (2) 17 full-term infants with IUGR whose birth weights ranged from 1870 to $2523 \mathrm{~g}$ and were below the tenth percentile lines shown on the intrauterine growth chart of LuBGHENco et al. [15]; and (3) 17 premature infants, born before the $37^{\text {th }}$ week of gestation, weighing 1588 to $3108 \mathrm{~g}$.

The infants were free of detectable congenital anomalies and had no major diseases. None needed treatment during the period of study. Each received routine nursery care. Fifteen of the normal full-term infants were fed a creatinine-free soya formula for the first week of life for purposes of studying daily endogenous creatinine excretion rates. Ten of the normal full-term infants were breast fed. All other infants received a cow's milk formula.

Twenty-four-hour urine samples were collected in plastic bags from each infant on the first day and from most of them on the third day of life. The bags were checked and emptied every few hours. Urine was acidified $(\mathrm{pH}<1)$ and stored frozen. To determine total hydroxyproline content of urine, hydrolysis was carried out as described by Prockop and UDENFriend [22]. The method of NEUMAN and Logan [20] as modified by Serafini-Cessi and Cessi [24] was then followed. Creatinine in urine was determined as described by GLARK [3] except that all samples, standards and blanks, were shaken with an equal volume of ether for three minutes before addition of $\mathrm{NaOH}$ to develop color, since we found that urine of newborn infants contains appreciable amounts of nonspecific chromogens.

\section{Results}

Table I presents the means for gestational age, weight, age at the start of the urine collection periods, urine volume per 24 hours and mean daily hydroxyproline excretion in the three groups of infants. In addition, it also contains the mean daily urinary creatinine excretion and hydroxyproline/creatinine ratio of the 15 normal full-term infants who were fed the soya formula. Urine volume was similar for all groups during each of the two collection periods. There appeared to be no relation between age at initiation of urine collection and the daily urine volume. Similarly, there was no correlation between the age at which urine collection was started and the amount of hydroxyproline and creatinine excreted per day. The amounts of hydroxyproline excreted during the first day of life were not significantly different among the three groups of infants. On the third day of life, however, all groups had

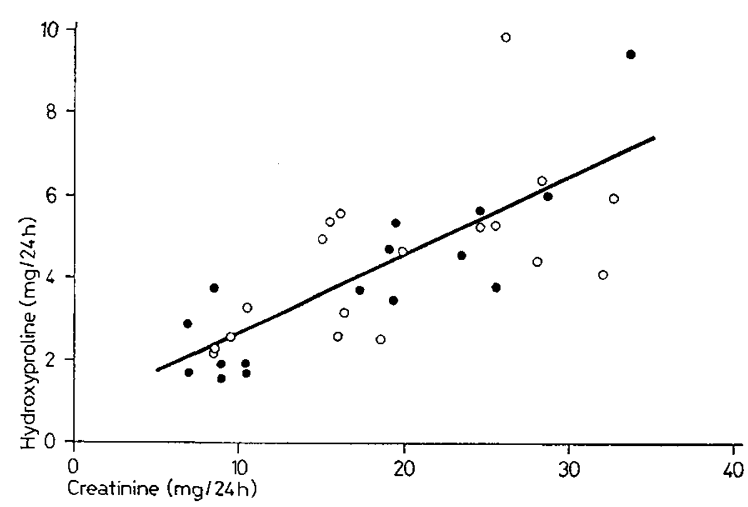

Fig.1. Correlation between total daily excretion of hydroxyproline and creatinine in 34 full-term normal infants on the first day of life.

Closed circle: males; open circles: females. $\mathrm{y}=0.20 \mathrm{x}+0.67 ; \mathrm{r}=0.773(\mathrm{p}<0.001)$.

a significantly greater amount of hydroxyproline in their urine $(p<0.01)$; premature and normal infants excreted approximately equal amounts, significantly more than IUGR infants $(p<0.02)$. There was no difference in the daily urinary excretion of hydroxyproline in full-term infants whether they were breast fed or received a cow's milk formula. Girls tended to excrete lesser amounts of hydroxyproline than boys during the second collection period, but the difference was not statistically significant $(t=1.463)$. The quantity of hydroxyproline excreted per 24 hours by infants in any one group had no significant correlation with body length, weight or urine volume. On the first day of life in premature and full-term infants, concentrations of hydroxyproline and creatinine had a significant negative correlation with the 24-hour urine volume when this was less than about $90 \mathrm{ml} /$ day. With higher volumes, no such correlation was observed. There was no correlation between concentrations of hydroxyproline and urine volume in the IUGR infants on the first day or in the three groups on the third day of life. In the full-term infants, the amount of hydroxyproline excreted per 24 hours had a significant positive correlation with the amount of creatinine excreted during the same period (fig. 1). The mean daily urinary creatinine excretion in $\mathrm{mg} / 24 \mathrm{~h}$ in the 15 infants fed a soya formula did not change over the first week of life, and was 24.2, 24.3 and 22.5 on the first, third and seventh day of age, respectively. The mean daily hydroxyproline/creatinine ratio, however, had doubled by the third day of life. The level of urinary excretion of creatinine in infants receiving the soya formula on the first day of life did not differ significantly from that of the 19 full-term infants on milk feedings. Urin- 
Excretion of hydroxyproline in urine by premature and normal full-term infants...

Table I. Clinical data and amounts of urinary hydroxyproline and creatinine excreted by normal full-term, intrauterine growth retarded (IUGR) and premature infants on the first and third days of life

\begin{tabular}{|c|c|c|c|c|c|c|}
\hline \multirow{2}{*}{$\frac{\text { Infants }}{\text { Age in days }}$} & \multicolumn{2}{|c|}{ Normal full-term } & \multicolumn{2}{|c|}{ IUGR } & \multicolumn{2}{|c|}{ Premature } \\
\hline & 1st day & 3rd day & 1st day & 3rd day & 1st day & 3rd day \\
\hline No. of infants studied & 50 & 29 & 15 & 17 & 16 & 15 \\
\hline Sex: (female $)-($ male $)$ & $(26)-(24)$ & $(16)-(13)$ & $(7)-(8)$ & $(8)-(9)$ & $(8)-(8)$ & $(6)-(9)$ \\
\hline Mean gestational age (weeks) & 40 & & 40 & & 34 & \\
\hline Mean birth weight $(\mathrm{g})$ & 3,424 & & 2,226 & & 2,131 & \\
\hline $\begin{array}{l}\text { Mean age at start of urine } \\
\text { collection }(\mathrm{h})\end{array}$ & 8.7 & 57.5 & 8.0 & 54 & 8.0 & 56.3 \\
\hline Mean 24-hour urine vol. (mI) & 49 & 118 & 54 & 100 & 58 & 97 \\
\hline $\begin{array}{l}\text { Urine hydroxyproline } \\
\mathrm{mg} / 24 \mathrm{~h}\left(\text { mean } \pm \mathrm{SE}^{1}\right) \\
(\mathrm{range}) \\
\mathrm{mg} / \mathrm{kgm} / 24 \mathrm{~h}^{3}\end{array}$ & $\begin{array}{l}4.4 \pm 1.00 \\
(1.8-10.4) \\
1.3\end{array}$ & $\begin{array}{l}9.9 \pm 0.82 \\
(4.5-20.1) \\
2.7\end{array}$ & $\begin{array}{l}3.5 \pm 0.71 \\
(0.4-8.5) \\
1.6\end{array}$ & $\begin{array}{l}7.0 \pm 0.60 \\
(3.5-12.1) \\
3.1\end{array}$ & $\begin{array}{l}5.5 \pm 0.55 \\
(1.5-9.8) \\
3.0\end{array}$ & $\begin{array}{l}9.6 \pm 0.91 \\
(5.8-18.6) \\
4.8\end{array}$ \\
\hline $\begin{array}{l}\text { Urine creatinine } \\
\mathrm{mg} / 24 \mathrm{~h}^{3}\end{array}$ & 24.2 & 24.3 & & & & \\
\hline $\begin{array}{l}\text { mg hydroxyproline } \\
\text { per mg creatine }\end{array}$ & 0.20 & 0.41 & & & & \\
\hline
\end{tabular}

1 Standard error of the mean

${ }^{2}$ Determined in 15 normal full-term infants fed a soya formula

${ }^{3}$ Mean values reported/24 $\mathrm{h}$

ary creatinine levels were not measured in the other infants. The daily excretion of hydroxyproline and creatinine was quite variable from day to day and from infant to infant.

\section{Discussion}

On the first day of life, the amount of hydroxyproline and creatinine excreted in the urine by the infants may have been affected by maternal blood levels, since the amounts of gelatine, creatine and creatinine were not restricted in the maternal diets. On the third day of life, however, the amount of hydroxyproline excreted in the urine may be considered as endogenous, since milk has no appreciable amount of hydroxyproline $[17,25]$. The values of urinary hydroxyproline excretion reported here for normal infants are similar to those recently reported in the literature. KLEIN and TERRE [12] found levels of excretion of 7.9-21.0 mg/ $24 \mathrm{~h}$ in five infants one to three days of age, and AlLIson et al. [1] reported a mean excretion of $8.9 \mathrm{mg} / 24 \mathrm{~h}$ for infants two to three days of age. Both groups of investigators showed very rapid increases in urinary hydroxyproline excretion over the first two months of life, with a concomitant increase in the daily hydroxyproline/creatinine ratios. We have shown a two-fold increase of the hydroxyproline/creatinine ratio in normal full-term infants over the first three days of life.
The question may be asked whether the rising urinary hydroxyproline excretion during early infancy is merely the result of maturing renal function or whether this represents a true increase, indicative of a progressively more active and expanding mass of collagen tissue associated with growth and gain in body length. Both glomerular and tubular functions have been shown to be decreased in the infant as compared with the adult. Augmentation of glomerular filtration rate may possibly have contributed to the increased amount of hydroxyproline excreted by the infant between the first and third day of life. Urea and creatinine clearance rates are apparently quite variable at this age, but they have not been shown to change appreciably during the first few days of life $[4,16,23]$. The total daily excretion of endogenous creatinine did not vary significantly over the first seven days of life in the 15 infants studied by us, although we did not measure creatinine clearance rates. Renal tubular reabsorption of hydroxyproline is probably impaired in early infancy. Improving tubular function, however, would result in a decreased urinary excretion of hydroxyproline and not an increase. We feel, therefore, that the increased amount of hydroxyproline excreted by infants over the first three days of life represents, to a large extent, a true rise associated with a rapid turnover and metabolism of collagen tissue during this period. 
In infants between 20 and 120 days of age, the rate of urinary endogenous hydroxyproline has been shown to have a significant positive correlation with the rate of change in body length [26]. If this correlation holds true also for the first days of life, then the low excretion rates observed at this age represent a state of relative collagen inactivity. This may be so, since intrauterine growth charts $[6,14]$ show decreased rates of growth (both weight and length) of the fetus toward the later weeks of gestation. Infants who have grown less rapidly in utero showed decreased hydroxyproline excretion over the first three days of life, whereas premature infants showed higher hydroxyproline excretion levels indicating, perhaps, a more rapid growth rate than IUGR infants. In the premature infant, however, diminished renal tubular reabsorption of hydroxyproline and hydroxyproline peptides may be contributing to increased urinary excretion.

The negative correlation between 24-hour urinary volume (up to $90 \mathrm{ml}$ ) and the concentrations of endogenous hydroxyproline and creatinine for the full-term and premature infants on the first day of life cannot be fully explained. Data on the fluid balance for all the infants were not available to ascertain their state of hydration and effect of hydration on urinary concentration of these substances. The positive correlation between rates of urinary excretion of endogenous hydroxyproline and creatinine for the full-term infants may be due to a close association of bone and muscle metabolism.

\section{Conclusion}

The low level of hydroxyproline excretion found in newborn infants on the first day of life may be a manifestation of relative collagen inactivity during the latter part of intrauterine life. The two-fold rise in hydroxyproline excretion which occurs over the first three days of life would suggest the initiation of a phase of rapid growth very soon after birth. The lesser amount of hydroxyproline excreted by IUGR infants on the third day of life, as compared to normal full-term and premature infants, would suggest less rapid growth. This observation may prove to be of some value in the diagnosis of conditions retarding growth during the perinatal period.

\section{References and Notes}

1. Allison, D.J.; Walker, A. and Smith, Q.T.: Urinary hydroxyproline: Creatinine ratio of normal humans at various ages. Clin. chim. Acta. 14: 729 (1966).

2. Grvapil, M. and Jackson, D.S.: Evidence of the degradative origin of free hydroxyproline and pep- tides containing hydroxyproline. Fourth National Collagen Symposium, Hluboka, May 1964. Collagen currents (Abstract) 5: 164 (1964).

3. CLARK, J.T.: Colorimetric determination and distribution of urinary creatinine and creatine. Clin. Chem. 1: 271 (1961).

4. Dean, R.F.A. and MaCance, R. A.: Inulin, diodone, creatinine and urea clearances in newborn infants. J. Physiol., Lond. 106: 431 (1947).

5. Dull, T.A. and Henneman, P.H.: Urinary hydroxyproline as an index of collagen turnover in bone. New Engl.J. Med. 268: 132 (1963).

6. Gruenwald, P.: Growth of the human fetus. I. Normal growth and its variations. J. Obstet. Gynec. 94: 1112 (1966).

7. HARris, E.D., Jr. and SJoerdsma, A.: Effect of parathyroid extract on collagen metabolism. J. clin. Endocr. 26: 358 (1966).

8. JAnsin, H. E. ; FinK, C.W.; Wise, W. and ZrFF, M. : Relationship between urinary hydroxyproline and growth. J. clin. Invest. 42: 1928 (1962).

9. Jones, C. R.; Bergman, M.W.; Kittner, P.J. and Pigman, W.W.: Urinary hydroxyproline excretion in normal children and adolescents. Proc.Soc. exp. Biol. (N.Y.) 115: 85 (1964).

10. Klein, L.; Albertsen, K. and Gurtiss, P.H., Jr.: Urinary hydroxyproline in hyperparathyroidism: A study of three cases with and without bone lesions. Metabolism 11: 1023 (1962).

11. KLeIN, L. and Gurtiss, P.H.,Jr. : Urinary hydroxyproline as an index of bone metabolism; in Dynamic studies of metabolic bone disease (ed. Pearson, O.H. and Jopun, G. F.), p. 201 (Blackwell, London 1964).

12. Klein, L. and Terre, T.M.: Skeletal metabolism in early infancy: Urinary hydroxyproline. J.Pediat. 69: 266 (1966).

13. Lindstedt, S. and Prockop, D.J.: Isotopic studies on urinary hydroxyproline as evidence for rapidly catabolized forms of collagen in the young rat. J. biol. Chem. 236: 1399 (1961).

14. Lubchenco, L.O.; Hansman, C. and Boyd, E.: Intrauterine growth in length and head circumference as estimated from live birth at gestational ages from 26 to 42 weeks. Pediatrics 37: 403 (1966).

15. Lubchenco, L.O.; Hansman, G.; Dressler, M. and BoyD, E.: Intrauterine growth as estimated from live born birth weight data at 24 to 42 weeks of gestation. Pediatrics 32: 793 (1963).

16. MaGance, R.A. and Wrddowson, E. M.: Normal renal function in the first two days of life. Arch. Dis. Ghildh. 29: 488 (1954).

17. MaCance, R.A. and Wrddowson, E.M.: The composition of foods. Spec.Rep.Ser.med.Res. coun. (Lond.) 297: 237 (1960). 
18. NAKAgAWA, M. and TAMAKI, T.: Urinary hydroxyproline excretion in orthopedic disease. Nagoya J. med. Sci. 27: 772 (1965).

19. Neuberger, A. and Slack, H.G.B.: The metabolism of collagen from liver, bone, skin and tendon in the normal rat. Biochem.J. 53: 47 (1953).

20. Neuman, R.E. and Logan, M.A.: The determination of hydroxyproline. J.biol. Chem. 184: 299 (1950).

21. Prockop, D. J. : Isotopic studies on collagen degradation and the urine excretion of hydroxyproline. J.clin. Invest. 43: 453 (1964).

22. Prockop, D.J. and Udenfriend, S.: A specific method for the analysis of hydroxyproline in tissues and urine. Anal. Biochem. 1: 228 (1960).

23. Rubin, M.I.; Bruck, E. and RApoport, M.: Maturation of renal function in childhood: Clearance studies. J. clin. Invest. 28: 1144 (1949).
24. Serafini-Cessi, F. and Cessi, C.: An improved method for determination of hydroxyproline in protein hydrolyzates. Anal. Biochem. 8: 527 (1964).

25. Soupart, P.; Standford, M. and Bigwood, E.J.: Amino acid composition of human milk. J.biol. Chem. 206: 699 (1954).

26. Younoszal, M.K.; Anderson, W.A.; FrLer, L.J., Jr., and Fomon, S.J.: Urinary excretion of endogenous hydroxyproline by normal male infants. Pediat. Res. 1: 266 (1967).

27. The authors acknowledge with thanks the technical assistance of Mrs. S. Ben, Mrs. L. Dilling, Mrs. J.PELOSO, Mrs. A. KaGic, and the nursing staff of the Women's Pavilion, Winnipeg General Hospital.

28. Younoszar, M.K., M.D., The Children's Hospital, Winnipeg 3, Manitoba (Canada). 